\title{
In vitro Screening of Oxime Reactivators on the Model of Paraoxon-inhibited Acetylcholinesterase-SAR Study
}

\author{
Ondrej Holas, Kamil Musilek, ${ }^{\dagger,, *}$ Miroslav Pohanka, ${ }^{\ddagger}$ Kamil Kuca, ${ }^{\ddagger \S}$ Veronika Opletalova, and Young-Sik Jung ${ }^{\sharp, *}$
}

Department of Pharmaceutical Chemistry and Drug Control, Faculty of Pharmacy in Hradec Kralove,

Charles University in Prague, Heyrovskeho 1203, 50005 Hradec Kralove, Czech Republic

'Department of Toxicology, Faculty of Military Health Sciences, Trebesska 1575, 50001 Hradec Kralove, Czech Republic

"E-mail:musilek@pmfhk.cz

${ }^{\ddagger}$ Center of Advanced Studies, Faculty of Military Health Sciences, Trebesska 1575, 50001 Hradec Kralove, Czech Republic

${ }^{\S}$ Department of Chemistry, Faculty of Science, University of Jan Evangelista Purkyne, Ceske mladeze 8 , 40096 Usti nad Labem, Czech Republic

\#Bioorganic Science Division, Korea Research Institute of Chemical Technology, P.O. Box 107, Yuseong, Daejeon 305-606, Korea. "E-mail: ysjung@krict.re.kr

Received January 13, 2010, Accepted April 12, 2010

\begin{abstract}
Acetylcholinesterase reactivators are crucial antidotes for the treatment of organophosphate intoxication. Standard in vitro test was chosen using a rat brain homogenate as the source of AChE. Screening of reactivation potency was performed with two concentration of reactivator $(1000 \mu \mathrm{M}$ and $10 \mu \mathrm{M})$. Results were compared to established reactivators pralidoxime, methoxime, HI-6, trimedoxime and obidoxime. More than 30 novel reactivators performed equal or better reactivation ability of $\mathrm{POX}$-inhibited $\mathrm{AChE}$ compared to currently used reactivators. The structure-activity relationship for reactivators of paraoxon-inhibited $\mathrm{AChE}$ was developed.
\end{abstract}

Key Words: Acetylcholinesterase, Pesticide, Reactivator, Structural requirements

\section{Introduction}

Acetylcholinesterase (AChE 3.1.1.7) belongs to the family of serine hydrolases. It plays a crucial role in the organism. ${ }^{1} \mathrm{AChE}$ terminates a nervous transmission via degrading a neurotransmitter acetylcholine within the synaptic cleft. ${ }^{2}$ Cavity of the enzyme is located in $20 \AA(20 \mathrm{~nm})$ deep gorge with active (A) site and peripheral $(\mathrm{P})$ site. $^{3,4} \mathrm{~A}$-site contains amino-acids residues of catalytic triad (S203, E334 and H447). ${ }^{5,6}$ P-site plays important role in allosteric modulation of the enzyme activity, it contains residues of Tyr72, Tyr124, Trp286, Tyr341 and Asp74. ${ }^{5}$ Organophosphorus compounds (OPCs) are able to inhibit AChE irreversibly. ${ }^{7}$ Many organophosphorus AChE inhibitors were synthesized and widely used as pesticides (e.g. parathion, paraoxon, chlorpyrifos, and diazinon) ${ }^{8,9}$ or industrial compounds (e.g. plasticizers and flame retardants). Some of them were developed for military purposes and they are known as nerve agents ${ }^{10}$ (e.g. sarin, soman, tabun, and VX). Some OPCs are shown in Figure 1. OPCs irreversibly inhibit AChE that cannot fulfil its physiological role. Intoxication is manifested by bronchial hypersecretion, salivation, muscle spasms and fasciculation leading to paralysis, depression of breathing centre followed by death. ${ }^{11,12}$

Moreover, inhibited enzyme undergoes a process called "aging" ${ }^{13}$ During this process, OPC-AChE complex is dealkylated. None of currently known reactivators is able to restore the $\mathrm{AChE}$ function after aging process. ${ }^{14}$

Standard treatment of OPC intoxication consists of AChE reactivators, anticholinergic drug (e.g. atropine) and anticonvulsive (e.g. diazepam). ${ }^{15} \mathrm{AChE}$ reactivators are able to counteract consequences of OPC intoxication and they are an essential part of the standard treatment. ${ }^{16}$ Reactivators are monoquaternary or bisquaternary pyridinium salts, which bear an oxime (hydroxy-<smiles>CC(C)OP(C)(=O)F</smiles>

sarin<smiles>CCOP(=O)(C#N)N(C)C</smiles>

tabun

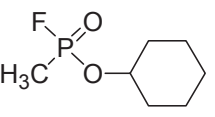

cyclosarin<smiles>CCOP(C)(=O)SCCN(C(C)C)C(C)C</smiles>

VX

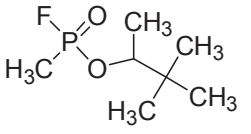

soman

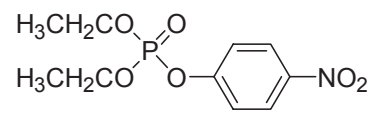

paraoxon

Figure 1. Organophosphorus inhibitors of AChE. 
<smiles></smiles>

pralidoxime (1)

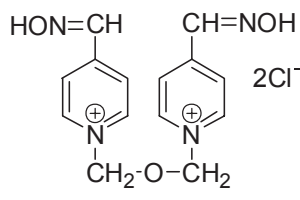

obidoxime (2)

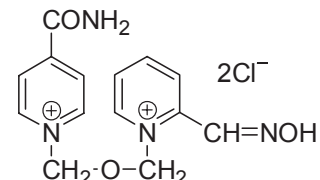

HI-6 (3)
Figure 2. Commercially available oxime reactivators.

iminomethyl) group in the molecule. ${ }^{17,18}$ Dissociated oximate anion is able to attack to the covalent bond in the AChE-OPC complex and restores the enzyme function. ${ }^{19}$ The pralidoxime (1, 2-hydroxyiminomethyl-1-methylpyridinium chloride), HI-6 (2, 1-(2-hydroxyiminomethylpyridinium)-3-(4-carbamoylpyridinium)-2-oxapropane dichloride) obidoxime (3, 1,3-bis(4-hydroxyiminomethylpyridinium)-2-oxapropane dichloride) are commercially available oxime reactivators ${ }^{20}$ (Figure 2). Atropine is used for binding to muscarinic acetylcholine receptors (AChR) with consequent neuronal transduction, therefore prevents from hyperstimulation with ACh and subsequent cholinergic crisis. ${ }^{21}$ Diazepam is used for anticonvulsive treatment. ${ }^{10}$

OP pesticides are easily available and used globally. Moreover, at least 200000 people annually die of OP pesticide selfpoisoning. ${ }^{8,22}$ Since there is a wide variety of OPCs, none of currently used compounds is able to fairly reactivate $\mathrm{AChE}$ inhibited by various pesticides. ${ }^{23}$ Additionally, commercial AChE re- activators were originally designed against nerve agents. Hence, new reactivators of OP pesticides are currently requested. ${ }^{24}$

In this study, paraoxon was chosen as model OPC for our in vitro screening. Though paraoxon is prohibited OP compound for several decades for its increased toxicity in human, its thioanalogue parathion may still be in use. Parathion is easily bioactivated via CYP-450 to paraoxon. ${ }^{25}$

\section{Results and Discussion}

The previously known compounds (1-7) and over 50 new reactivators (8-63) were assayed for their reactivation ability using rat brain homogenate inhibited by paraoxon. The reactivation results are listed in Table 1-9.

A reactivation in vitro should exceed $10 \%$ to suggest a promising compound warranting further testing. ${ }^{17,26}$ Apparently, not all of the tested compounds were able to fulfil this requirement. Moreover, maximal attainable plasma concentration of reactivator is $100 \mu \mathrm{M} .{ }^{27}$ Consequently, reactivation ability at 10 $\mu \mathrm{M}$ is more relevant concerning further testing and plausible use. Reactivation potency of oximes is better for POX-inhibited $\mathrm{AChE}$ comparing to nerve agents, because they undergo slower or no "aging" process. ${ }^{28}$

The best reactivation results among standard compounds were obtained for compounds $2,4,6$ and 7 with concentration $1000 \mu \mathrm{M}$ and $\mathbf{2}$ and $\mathbf{5}$ (obidoxime and trimedoxime) with con-

Table 1. Reactivation potency of commercial and standard reactivators

\begin{tabular}{|c|c|c|c|c|c|c|}
\hline \multirow{2}{*}{ Reactivator } & \multicolumn{4}{|c|}{ 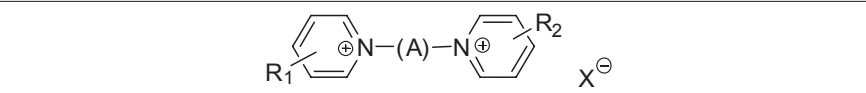 } & \multicolumn{2}{|c|}{$\%$ reactivation $\pm \mathrm{SD}$} \\
\hline & $\mathrm{R}_{1}$ & $\mathrm{R}_{2}$ & A & $\mathrm{X}$ & $1000 \mu \mathrm{M}$ & $10 \mu \mathrm{M}$ \\
\hline 1 (Pralidoxime) & $2-\mathrm{CH}=\mathrm{NOH}$ & - & $\mathrm{CH}_{3}$ & I & $42 \pm 1$ & 0 \\
\hline 2 (Obidoxime) & $4-\mathrm{CH}=\mathrm{NOH}$ & $4-\mathrm{CH}=\mathrm{NOH}$ & $\mathrm{CH}_{2} \mathrm{OCH}_{2}$ & $2 \mathrm{Cl}$ & $76 \pm 2$ & $37 \pm 2$ \\
\hline 3 (HI-6) & $2-\mathrm{CH}=\mathrm{NOH}$ & 4- $\mathrm{CONH}_{2}$ & $\mathrm{CH}_{2} \mathrm{OCH}_{2}$ & $2 \mathrm{Cl}$ & $35 \pm 2$ & 0 \\
\hline 4 & $4-\mathrm{CH}=\mathrm{NOH}$ & $4-\mathrm{CH}=\mathrm{NOH}$ & $\mathrm{CH}_{2}$ & $2 \mathrm{Br}$ & $71 \pm 3$ & 0 \\
\hline 5 & $4-\mathrm{CH}=\mathrm{NOH}$ & $4-\mathrm{CH}=\mathrm{NOH}$ & $\left(\mathrm{CH}_{2}\right)_{3}$ & $2 \mathrm{Br}$ & $46 \pm 1$ & $50 \pm 4$ \\
\hline 6 & $4-\mathrm{CH}=\mathrm{NOH}$ & 4- $\mathrm{CONH}_{2}$ & $\left(\mathrm{CH}_{2}\right)_{3}$ & $2 \mathrm{Br}$ & $59 \pm 4$ & $21 \pm 1$ \\
\hline 7 & $4-\mathrm{CH}=\mathrm{NOH}$ & 4- $\mathrm{CONH}_{2}$ & $\left(\mathrm{CH}_{2}\right)_{4}$ & $2 \mathrm{Br}$ & $57 \pm 4$ & $5 \pm 2$ \\
\hline
\end{tabular}

Table 2. Reactivation potency of bisoxime xylene linked reactivators

\begin{tabular}{|c|c|c|c|c|}
\hline \multirow[t]{2}{*}{ Reactivator } & \multicolumn{2}{|c|}{$\mathrm{HON}=\mathrm{HC} \stackrel{\oplus}{=}-(\mathrm{A})-\Perp^{\oplus}>2 \mathrm{Br}^{\ominus}$} & \multicolumn{2}{|c|}{$\%$ reactivation $\pm \mathrm{SD}$} \\
\hline & Oxime position & Linker (A) & $1000 \mu \mathrm{M}$ & $10 \mu \mathrm{M}$ \\
\hline 8 & $2,3^{\prime}$ & $o$-phenylene & 0 & 0 \\
\hline 9 & $2,4^{\prime}$ & $o$-phenylene & 0 & 0 \\
\hline 10 & $3,4^{\prime}$ & $o$-phenylene & 0 & 0 \\
\hline 11 & $2,3^{\prime}$ & $m$-phenylene & 0 & $49 \pm 4$ \\
\hline 12 & $2,4^{\prime}$ & $m$-phenylene & 0 & $53 \pm 3$ \\
\hline 13 & $3,4^{\prime}$ & $m$-phenylene & 0 & 0 \\
\hline 14 & $2,3^{\prime}$ & $p$-phenylene & 0 & $46 \pm 1$ \\
\hline 15 & $2,4^{\prime}$ & p-phenylene & 0 & $53 \pm 6$ \\
\hline 16 & $3,4^{\prime}$ & $p$-phenylene & 0 & 0 \\
\hline
\end{tabular}


Table 3. Reactivation potency of bisoxime xylene linked reactivators

\begin{tabular}{|c|c|c|c|c|}
\hline \multirow[t]{2}{*}{ Reactivator } & \multicolumn{2}{|c|}{ 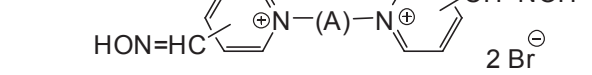 } & \multicolumn{2}{|c|}{$\%$ reactivation $\pm \mathrm{SD}$} \\
\hline & Oxime position & A & $1000 \mu \mathrm{M}$ & $10 \mu \mathrm{M}$ \\
\hline 17 & $2,2^{\prime}$ & $\left(\mathrm{CH}_{2}\right)_{3}$ & $16 \pm 2$ & 0 \\
\hline 18 & 3,3 & $\left(\mathrm{CH}_{2}\right)_{3}$ & $9 \pm 0$ & 0 \\
\hline 19 & $2,3^{\prime}$ & $\left(\mathrm{CH}_{2}\right)_{3}$ & $33 \pm 1$ & $12 \pm 0$ \\
\hline 20 & $2,4^{\prime}$ & $\left(\mathrm{CH}_{2}\right)_{3}$ & $25 \pm 0$ & $38 \pm 0$ \\
\hline 21 & $3,4^{\prime}$ & $\left(\mathrm{CH}_{2}\right)_{3}$ & $41 \pm 1$ & $43 \pm 2$ \\
\hline
\end{tabular}

Table 4. Reactivation potency of monooxime-monocyano propane linked reactivators

\begin{tabular}{|c|c|c|c|c|}
\hline \multirow[t]{2}{*}{ Reactivator } & $\mathrm{HON}=\mathrm{HC}$ & & \multicolumn{2}{|c|}{$\%$ reactivation $\pm \mathrm{SD}$} \\
\hline & Substituent position & A & $1000 \mu \mathrm{M}$ & $10 \mu \mathrm{M}$ \\
\hline 22 & $3,4^{\prime}$ & $\left(\mathrm{CH}_{2}\right)_{3}$ & $4 \pm 0$ & $25 \pm 0$ \\
\hline 23 & $2,4^{\prime}$ & $\left(\mathrm{CH}_{2}\right)_{3}$ & 0 & 0 \\
\hline 24 & $4,4^{\prime}$ & $\left(\mathrm{CH}_{2}\right)_{3}$ & $32 \pm 3$ & $3 \pm 1$ \\
\hline
\end{tabular}

Table 5. Reactivation potency of monooxime-monocarbamoyl $(E)$ but-2-en linked reactivators

\begin{tabular}{|c|c|c|c|c|}
\hline \multirow{2}{*}{ Reactivator } & $\mathrm{HON}=\mathrm{HC}$ & 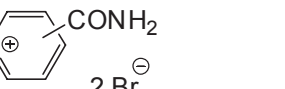 & \multicolumn{2}{|c|}{$\%$ reactivation \pm SD } \\
\hline & Substituent position & A & $1000 \mu \mathrm{M}$ & $10 \mu \mathrm{M}$ \\
\hline 25 & $2,4^{\prime}$ & (E) $\mathrm{CH}_{2} \mathrm{CH}=\mathrm{CHCH}_{2}$ & $44 \pm 1$ & $39 \pm 3$ \\
\hline 26 & $3,4^{\prime}$ & (E) $\mathrm{CH}_{2} \mathrm{CH}=\mathrm{CHCH}_{2}$ & $16 \pm 0$ & 0 \\
\hline 27 & $4,4^{\prime}$ & (E) $\mathrm{CH}_{2} \mathrm{CH}=\mathrm{CHCH}_{2}$ & $64 \pm 3$ & $23 \pm 1$ \\
\hline 28 & 2,3 & (E) $\mathrm{CH}_{2} \mathrm{CH}=\mathrm{CHCH}_{2}$ & $18 \pm 1$ & $33 \pm 4$ \\
\hline 29 & 3,3 & (E) $\mathrm{CH}_{2} \mathrm{CH}=\mathrm{CHCH}_{2}$ & 0 & $25 \pm 0$ \\
\hline 30 & $4,3^{\prime}$ & (E) $\mathrm{CH}_{2} \mathrm{CH}=\mathrm{CHCH}_{2}$ & $54 \pm 0$ & $49 \pm 0$ \\
\hline
\end{tabular}

centration $10 \mu \mathrm{M}$. Other commercial reactivators $(\mathbf{1}, \mathbf{3}$ and $\mathbf{4})$ were not convenient for reactivation of POX-inhibited AChE in vivo.

Some newly tested reactivators showed promising results, mainly for concentration $10 \mu \mathrm{M}$. Promising compounds, which showed better results compared to the group of standards, were mainly the reactivators with xylene and but-2-ene linkage (11, $12,14,15,25,27,33,44,56,62)$. Hence, some structural features were found more beneficial for reactivation of POX-inhibited AChE. In addition, interesting phenomenon was observed, where some compounds showed higher reactivation ability for lower concentration of the reactivator (e.g. 11-12, 14-15, 20-22, 28-29, 32-36, 58, 61-63). This was probably caused by coincident reactivation and inhibition of the enzyme by reactivator itself as was described earlier. ${ }^{24}$

Structural requirements for oxime reactivators were previously described. ${ }^{19,29,30}$ Some authors used molecular modelling to predict the most effective structure of oxime reactivators, too. ${ }^{4,13}$ The main structural features that influence the reactivation abili- ty are the oxime functional group (its position and amount), number of quaternary nitrogen, varying functional group on non-oxime heteroaromatic ring and the connecting linker (its length and structure) for bisquarternary reactivators. ${ }^{24,31}$

Oxime functional group is essential for reactivation process. For POX-inhibited $\mathrm{AChE}$, at least one oxime group in position four (30) seemed to be beneficial, when compared to related compounds with the oxime in position two $(\mathbf{1 7}, \mathbf{2 8})$ or three $(\mathbf{1 8}$, 29), especially for $10 \mu \mathrm{M}$. Compounds with oxime group in position 3 were much less effective (26 compared to 25 and 27 ) that was formerly explained by increased $\mathrm{p} K_{\mathrm{a}}$ of 3 -positioned oxime. ${ }^{17}$ Furthermore, the reactivation results showed that one oxime group was essential and introduction of second oxime didn't lead to significant increase of reactivation ability (25-30 compared to 56-58).

Differently, the non-oxime functional group may extend the hydrophilic/hydrophobic interactions within the enzyme active sites. ${ }^{32}$ From this point of view, the best results were obtained for the isoquinolinium-monooxime reactivator (62; Table 9). In this 
Table 6. Reactivation potency of bisoxime (Z) but-2-ene linked reactivators

\begin{tabular}{|c|c|c|c|c|}
\hline \multirow{2}{*}{ Reactivator } & \multicolumn{2}{|c|}{ 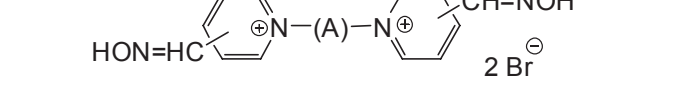 } & \multicolumn{2}{|c|}{$\%$ reactivation $\pm \mathrm{SD}$} \\
\hline & Oxime position & A & $1000 \mu \mathrm{M}$ & $10 \mu \mathrm{M}$ \\
\hline 31 & $2,2^{\prime}$ & (Z) $\mathrm{CH}_{2} \mathrm{CH}=\mathrm{CHCH}_{2}$ & $26 \pm 1$ & $13 \pm 0$ \\
\hline 32 & 3,3 & (Z) $\mathrm{CH}_{2} \mathrm{CH}=\mathrm{CHCH}_{2}$ & $5 \pm 1$ & $8 \pm 1$ \\
\hline 33 & $4,4^{\prime}$ & (Z) $\mathrm{CH}_{2} \mathrm{CH}=\mathrm{CHCH}_{2}$ & $40 \pm 6$ & $46 \pm 1$ \\
\hline 34 & $2,3^{\prime}$ & (Z) $\mathrm{CH}_{2} \mathrm{CH}=\mathrm{CHCH}_{2}$ & 0 & $14 \pm 0$ \\
\hline 35 & $2,4^{\prime}$ & (Z) $\mathrm{CH}_{2} \mathrm{CH}=\mathrm{CHCH}_{2}$ & $19 \pm 2$ & $29 \pm 1$ \\
\hline 36 & $3,4^{\prime}$ & (Z) $\mathrm{CH}_{2} \mathrm{CH}=\mathrm{CHCH}_{2}$ & $3 \pm 0$ & $18 \pm 1$ \\
\hline
\end{tabular}

Table 7. Reactivation potency of monoxime $(E)$ but-2-ene linked reactivators

\begin{tabular}{|c|c|c|c|c|c|}
\hline \multirow[t]{2}{*}{ Reactivator } & \multicolumn{3}{|c|}{ 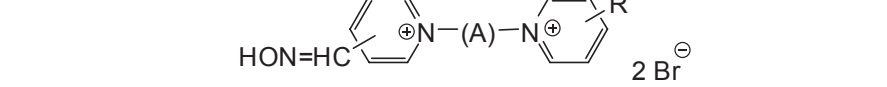 } & \multicolumn{2}{|c|}{$\%$ reactivation $\pm \mathrm{SD}$} \\
\hline & Oxime position & $\mathrm{R}$ & A & $1000 \mu \mathrm{M}$ & $10 \mu \mathrm{M}$ \\
\hline 37 & 4 & 4-COOH & (E) $\mathrm{CH}_{2} \mathrm{CH}=\mathrm{CHCH}_{2}$ & $63 \pm 1$ & $15 \pm 5$ \\
\hline 38 & 4 & $4-\mathrm{COOCH}_{3}$ & (E) $\mathrm{CH}_{2} \mathrm{CH}=\mathrm{CHCH}_{2}$ & $68 \pm 2$ & $36 \pm 2$ \\
\hline 39 & 4 & 4-COOEt & (E) $\mathrm{CH}_{2} \mathrm{CH}=\mathrm{CHCH}_{2}$ & $68 \pm 2$ & $30 \pm 2$ \\
\hline 40 & 4 & 4-fenyl & (E) $\mathrm{CH}_{2} \mathrm{CH}=\mathrm{CHCH}_{2}$ & $13 \pm 0$ & $22 \pm 0$ \\
\hline 41 & 4 & 4-benzyl & (E) $\mathrm{CH}_{2} \mathrm{CH}=\mathrm{CHCH}_{2}$ & 0 & $14 \pm 1$ \\
\hline 42 & 4 & - & (E) $\mathrm{CH}_{2} \mathrm{CH}=\mathrm{CHCH}_{2}$ & $57 \pm 0$ & $22 \pm 2$ \\
\hline 43 & 4 & $4-\mathrm{CN}$ & (E) $\mathrm{CH}_{2} \mathrm{CH}=\mathrm{CHCH}_{2}$ & $28 \pm 2$ & $20 \pm 0$ \\
\hline 44 & 4 & $4-\mathrm{CH}_{2} \mathrm{OH}$ & (E) $\mathrm{CH}_{2} \mathrm{CH}=\mathrm{CHCH}_{2}$ & $50 \pm 0$ & $42 \pm 0$ \\
\hline 45 & 4 & $4-\mathrm{C}_{2} \mathrm{H}_{4} \mathrm{SO}_{3} \mathrm{H}$ & (E) $\mathrm{CH}_{2} \mathrm{CH}=\mathrm{CHCH}_{2}$ & $67 \pm 2$ & $6 \pm 4$ \\
\hline 46 & 4 & $4-\mathrm{SCH}_{2} \mathrm{COOH}$ & (E) $\mathrm{CH}_{2} \mathrm{CH}=\mathrm{CHCH}_{2}$ & $13 \pm 1$ & $6 \pm 0$ \\
\hline 47 & 4 & $4-\mathrm{CH}_{3}$ & (E) $\mathrm{CH}_{2} \mathrm{CH}=\mathrm{CHCH}_{2}$ & $61 \pm 1$ & $26 \pm 2$ \\
\hline 48 & 4 & 4-t-butyl & (E) $\mathrm{CH}_{2} \mathrm{CH}=\mathrm{CHCH}_{2}$ & $52 \pm 1$ & $14 \pm 1$ \\
\hline 49 & 4 & $4-\mathrm{N}\left(\mathrm{CH}_{3}\right)_{2}$ & (E) $\mathrm{CH}_{2} \mathrm{CH}=\mathrm{CHCH}_{2}$ & 0 & $8 \pm 1$ \\
\hline 50 & 4 & 4-COOH & (E) $\mathrm{CH}_{2} \mathrm{CH}=\mathrm{CHCH}_{2}$ & $63 \pm 1$ & $15 \pm 5$ \\
\hline 51 & 4 & 4-( $\left.\mathrm{NH}_{2}\right) \mathrm{NOH}$ & (E) $\mathrm{CH}_{2} \mathrm{CH}=\mathrm{CHCH}_{2}$ & $52 \pm 2$ & $32 \pm 1$ \\
\hline
\end{tabular}

case, the weak interactions (e.g. cation- $\pi$ or $\pi-\pi$ ) and spatial orientation of the molecule $\mathbf{6 2}$ are probably essential for good reactivation ability, if compared to very similar quinolinium compound 61. On the other hand, it is not clear, if hydrophilic or hydrophobic moiety had increased influence on reactivation of POX-AChE complex. Among reactivators with lipophilic moieties, the methyl and phenyl derivatives (40 and 47) exceeded the properties of $t$-butyl and benzyl (41 and 48) reactivators at 10 $\mu \mathrm{M}$. In the group of hydrophilic substituted reactivators, the best results were obtained for structures with methylcarbonyl, ethylcarboxyl and hydroxymethyl functional groups $(38,39$ and 44).

Additionally, compounds with two quaternary pyridinium rings had better reactivation ability compared to monoquaternary reactivators $(1,53-54$ compared to $5,12,15,30,44,56$, 62). ${ }^{5,33}$ This fact arises from cation- $\pi$ interactions in the enzyme active sites. Besides this, monoquaternary reactivators significantly improved penetration through BBB compared to bisquaternary compounds, where small and only mono-charged molecules are more valuable. ${ }^{34,35}$
Regarding the connecting linker, an optimal length of the aliphatic linker for POX-inhibited AChE ranges from 3 to 4 methylene units $(\mathbf{5}, \mathbf{6}, \mathbf{2 0 - 2 1})$ as was formerly reported. ${ }^{19}$ This structural requirement may be described by spatial distance of two pyridinium moieties that are responsible for crucial cation- $\pi$ interactions within the $\mathrm{AChE}$ active sites and thus higher affinity towards AChE. Among the reactivators with propane linker, the best results were obtained with standard reactivator $\mathbf{5}$ and $\mathbf{6}$ and with new reactivators 19-21 for concentration $1000 \mu \mathrm{M}$. Same reactivators performed best results for concentration $10 \mu \mathrm{M}$ with exception of compound 19. Reactivators with $(E)$-but-2-ene linker showed promising reactivation potency mostly for oximes $\mathbf{2 5}, \mathbf{3 0}, \mathbf{3 8}, \mathbf{4 4}, \mathbf{5 6}$ and $\mathbf{6 2}$ for both concentrations. In the group of ( $Z$ )-but-2-ene linked reactivators, the best results were obtained for oximes $\mathbf{3 1}$ and $\mathbf{3 3}$ for concentration $1000 \mu \mathrm{M}$ and $\mathbf{3 3}$ and 35 for $10 \mu \mathrm{M}$ concentration. (E)-But-2-ene linked compounds resulted as more valuable when compared to $(Z)$-but-2-ene linked reactivators (56 and $\mathbf{5 8}$ to 33-34). ${ }^{31,36}$ The reactivation ability of the xylene linked compounds was influenced by higher linker rigidity, where xylene linker is spatially plain structure 
Table 8. Reactivation potency of monoquaternary and bisquaternary oxime reactivators

\begin{tabular}{|c|c|c|c|c|c|c|}
\hline \multirow[t]{2}{*}{ Reactivator } & \multicolumn{4}{|c|}{ 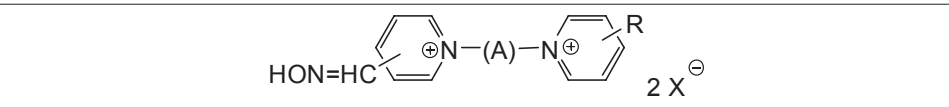 } & \multicolumn{2}{|c|}{$\%$ reactivation $\pm \mathrm{SD}$} \\
\hline & Oxime position & $\mathrm{R}$ & A & $\mathrm{X}$ & $1000 \mu \mathrm{M}$ & $10 \mu \mathrm{M}$ \\
\hline 52 & $4-\mathrm{CH}=\mathrm{NOH}$ & 4- $\left(\mathrm{NH}_{2}\right) \mathrm{NOH}$ & (E) $\mathrm{CH}_{2} \mathrm{CH}=\mathrm{CHCH}_{2}$ & & $52 \pm 2$ & $32 \pm 1$ \\
\hline 53 & $3-\mathrm{CH}=\mathrm{NOH}$ & - & $-\mathrm{CH}_{3}$ & $\mathrm{I}^{-}$ & $12 \pm 3$ & $11 \pm 0$ \\
\hline 54 & $4-\mathrm{CH}=\mathrm{NOH}$ & - & $-\mathrm{CH}_{3}$ & $\mathrm{I}^{-}$ & $40 \pm 0$ & 0 \\
\hline 55 & $2-\mathrm{CH}=\mathrm{NOH}$ & $2-\mathrm{CH}=\mathrm{NOH}$ & $\left(\mathrm{CH}_{2}\right)_{4}$ & $2 \mathrm{Br}^{-}$ & $32 \pm 3$ & $33 \pm 2$ \\
\hline 56 & $4-\mathrm{CH}=\mathrm{NOH}$ & $4-\mathrm{CH}=\mathrm{NOH}$ & (E) $\mathrm{CH}_{2} \mathrm{CH}=\mathrm{CHCH}_{2}$ & $2 \mathrm{Br}^{-}$ & $60 \pm 1$ & $46 \pm 2$ \\
\hline 57 & $2-\mathrm{CH}=\mathrm{NOH}$ & $2-\mathrm{CH}=\mathrm{NOH}$ & (E) $\mathrm{CH}_{2} \mathrm{CH}=\mathrm{CHCH}_{2}$ & $2 \mathrm{Br}^{-}$ & 0 & $8 \pm 2$ \\
\hline 58 & $2-\mathrm{CH}=\mathrm{NOH}$ & $3-\mathrm{CH}=\mathrm{NOH}$ & (E) $\mathrm{CH}_{2} \mathrm{CH}=\mathrm{CHCH}_{2}$ & $2 \mathrm{Br}^{-}$ & $28 \pm 2$ & $34 \pm 2$ \\
\hline
\end{tabular}

Table 9. Reactivation potency of monooxime reactivators - different heteroaromatic structures

\begin{tabular}{|c|c|c|c|}
\hline \multirow{2}{*}{ Reactivator } & \multirow{2}{*}{ Structure } & \multicolumn{2}{|c|}{$\%$ reactivation $\pm \mathrm{SD}$} \\
\hline & & $1000 \mu \mathrm{M}$ & $10 \mu \mathrm{M}$ \\
\hline 59 & & $35 \pm 6$ & $23 \pm 0$ \\
\hline 60 & & $34 \pm 0$ & 0 \\
\hline 61 & & 0 & $15 \pm 1$ \\
\hline 62 & & $43 \pm 0$ & $48 \pm 4$ \\
\hline 63 & & $14 \pm 1$ & $30 \pm 1$ \\
\hline
\end{tabular}

with limited possibilities of free rotation in comparison to aliphatic linkers (e.g. propane). Thus, the only bonds accessible for free rotation in xylene compounds are methylene junctions. These cause the non-coplanar formation of each pyridinium ring versus the xylene ring. Subsequently, the spatial orientation of xylene molecule is shifted, when compared to compound with aliphatic linker. In addition, better results (namely at $10 \mu \mathrm{M}$ ) for xylene reactivators were obtained for compounds with spatially more opened molecules with $m$ - or $p$-xylene linker $(\mathbf{1 1}, \mathbf{1 2}, 14$ and 15). ${ }^{37}$ The explanation of these results consist in entering the narrow AChE active gorge (about $5 \AA$ ), where $o$-xylene linked molecules are too bulky for going inside and consequently for successful reactivation. Generally, reactivators with double bond or xylene presented better reactivation ability compared to compounds with aliphatic linkers (7 compared to 27, 7 compared to 12 and 15). These differences were plausibly caused by the presence of the $\pi$-electrons in the connection chain and subsequent interactions with aromatic residues (His, Phe, Trp, Tyr) from $\mathrm{AChE}$ active sites. ${ }^{38}$

\section{Conclusions}

56 new potential AChE reactivators were tested in vitro and compared to the commercial compounds on the model of paraoxon-inhibited rat brain AChE. Structure-activity relationship was studied within this series compounds. More than 30 tested 
reactivators showed promising results at $10 \mu \mathrm{M}$ that is attainable concentration after in vivo administration. The best reactivation results were obtained for bisquarternary molecules with at least one oxime group in position 4 and with connecting linker ranging from 3 to $4 \mathrm{C}-\mathrm{C}$ bonds.

\section{Material and Methods}

All chemicals were purchased from Fluka or Sigma-Aldrich and used without further purification. Commercial and novel reactivators were synthesized in the Department of Toxicology (Faculty of Military Health Sciences, University of Defence). Their purity was verified by NMR and HPLC-MS methods. $10 \%$ rat brain homogenate was used as a source of AChE.

In vitro testing of reactivators was formerly described in detail. ${ }^{17}$ This method was chosen instead of Ellman's method to prevent oximolysis at higher oxime concentrations. Briefly, the $10 \%$ rat brain homogenate in distilled water was used as a source of AChE. The brain homogenate $(0.5 \mathrm{~mL})$ was mixed with of 1 $\mathrm{mM}$ isopropanol solution paraoxon $(20 \mu \mathrm{L} ; O, O$-diethyl-O-(4nitrophenyl)phosphate, analytical standard $99.2 \%$ from SigmaAldrich) and distilled water $(0.5 \mathrm{~mL})$. The mixture was incubated at $25{ }^{\circ} \mathrm{C}$ for $30 \mathrm{~min}$ and $95 \%$ inhibition of AChE was achieved. The mixture was filled in assay vessel to the volume $23 \mathrm{~mL}$ with distilled water and sodium chloride $(3 \mathrm{M}, 2.5 \mathrm{~mL})$ was added. Finally, acetylcholine iodide $(0.02 \mathrm{M}, 2 \mathrm{~mL}$; substrate for enzymatic reaction) was added. The enzyme activity (analyzed by potentiometric titration of decomposed acetylcholine iodide) was measured at $\mathrm{pH} 7.6$ and $25^{\circ} \mathrm{C}$ using an autotitrator RTS 822 (Radiometer, Denmark).

The same procedure was repeated with inhibited homogenate $(0.8 \mathrm{~mL})$ further subjected to $10 \mathrm{~min}$ incubation with an aqueous solution of reactivator $(0.2 \mathrm{ml}$ of $1 \mathrm{mM}$ or $10 \mu \mathrm{M})$, which replaced $0.2 \mathrm{~mL}$ of water. All measurements were done in triplicate. Activities of intact AChE $\left(\mathrm{a}_{0}\right)$, inhibited $\mathrm{AChE}\left(\mathrm{a}_{\mathrm{i}}\right)$ and reactivated $\mathrm{AChE}\left(\mathrm{a}_{\mathrm{r}}\right)$ were deduced from the consumption of $\mathrm{NaOH}$ solution $(0.01 \mathrm{M})$ in time. The percentage of reactivation $(\%)$ was calculated from the measured data according to the formula:

$$
x=\left(1-\frac{\mathrm{a}_{0}-\mathrm{a}_{\mathrm{r}}}{\mathrm{a}_{0}-\mathrm{a}_{\mathrm{i}}}\right) \cdot 100[\%]
$$

Acknowledgments. The authors express their appreciation to Mrs. M. Hrabinova for her technical assistance. The work was supported by Grant Agency of Ministry of Education, Youth and Sports (Czech Republic, No. ME09086). This work was also supported by the Korean Ministry of Education Science \& Technology (No. K20702000710-08B1200-01910).

\section{References}

1. Patocka, J.; Kuca, K.; Jun, D. Acta Medica 2004, 47, 215.

2. Rosenberry, T. L. Adv. Enzymol. Relat. Areas Mol. Biol. 1975, 43, 103.

3. Quinn, D. M. Chem. Rev. 1987, 87, 955.
4. Ekstrom, F.; Pang, Y. P.; Boman, M.; Artursson, E.; Akfur, C.; Borjegren, S. Biochem. Pharmacol. 2006, 72, 597.

5. Harel, M.; Schalk, I.; Ehretsabatier, L.; Bouet, F.; Goeldner, M.; Hirth, C.; Axelsen, P. H.; Silman, I.; Sussman, J. L. PNAS 1993, 90, 9031.

6. Saxena, A.; Fedorko, J. M.; Vinayaka, C. R.; Medhekar, R.; Radic, Z.; Taylor, P.; Lockridge, O.; Doctor, B. P. Europ. J. Biochem. 2003, $270,4447$.

7. Marrs, T. C. Pharmacol. Ther. 1993, 58, 51.

8. Eddleston, M.; Buckley, N. A.; Eyer, P.; Dawson, A. H. Lancet 2008, 371, 597.

9. Stone, D. L.; Sudakin, D. L. Clin. Toxicol. 2009, 47, 69.

10. Bajgar, J. Adv. Clin. Chem. 2004, 38, 151.

11. Costa, L. G. Clin. Chim. Acta 2006, 366, 1.

12. Rosenstock, L.; Keifer, M.; Daniell, W. E.; Mcconnell, R.; Claypoole, K. Lancet 1991, 338, 223.

13. Ekstrom, F.; Akfur, C.; Tunemalm, A. K.; Lundberg, S. Biochemistry 2006, 45, 74 .

14. Viragh, C.; Kovach, I. M.; Pannell, L. Biochemistry 1999, 38, 9557.

15. Bajgar, J.; Fusek, J.; Kuca, K.; Bartosova, L.; Jun, D. Mini. Rev. Med. Chem. 2007, 7, 461.

16. Kassa, J. J. Toxicol. Clin. Toxicol. 2002, 40, 803.

17. Kuca, K.; Patocka, J.; Cabal, J.; Jun, D. Neurotox. Res. 2004, 6, 565 .

18. Kovarik, Z.; Calic, M.; Sinko, G.; Bosak, A.; Berend, S.; Vrdoljak, A. L.; Radic, B. Chem. Biol. Interact. 2008, 175, 173.

19. Kuca, K.; Jun, D.; Musilek, K. Mini. Rev. Med. Chem. 2006, 6, 269.

20. Musilek, K.; Kuca, K.; Jun, D.; Dolezal, M. Curr. Org. Chem. 2007, 11, 229

21. Pohanka, M.; Karasova, J. Z.; Musilek, K.; Kuca, K.; Kassa, J. J. Appl. Toxicol. 2009, 29, 483 .

22. Eddleston, M.; Phillips, M. R. Brit. Med. J. 2004, 328, 42.

23. Jun, D.; Musilova, L.; Kuca, K.; Kassa, J.; Bajgar, J. Chem. Biol. Interact. 2008, 175, 421 .

24. Musilek, K.; Holas, O.; Kuca, K.; Jun, D.; Dohnal, V.; Opletalova, V.; Dolezal, M. Bioorg. Med. Chem. Lett. 2007, 17, 3172.

25. Park, N. J.; Jung, Y. S.; Musilek, K.; Jun, D.; Kuca, K. Bull. Korean Chem. Soc. 2006, 27, 1401.

26. Kuca, K.; Jun, D.; Bajgar, J. Drug Chem. Toxicol. 2007, $30,31$.

27. Tattersall, J. E. Br. J. Pharmacol. 1993, 108, 1006.

28. Eddleston, M.; Eyer, P.; Worek, F.; Mohamed, F.; Senarathna, L.; von Meyer, L.; Juszczak, E.; Hittarage, A.; Azhar, S.; Dissanayake, W.; Sheriff, M. H. R.; Szinicz, L.; Dawson, A. H.; Buckley, N. A. Lancet 2005, 366, 1452

29. Kuca, K.; Jun, D.; Bajgar, J. Curr. Pharm. Design 2007, 13, 3445.

30. Kuca, K.; Racakova, V.; Jun, D. Chem. Pap. 2007, 61, 256.

31. Musilek, K.; Holas, O.; Kuca, K.; Jun, D.; Dohnal, V.; Opletalova, V.; Dolezal, M. J. Enzym. Inhib. Med. Chem. 2008, 23, 70.

32. Cabal, J.; Kuca, K.; Kassa, J. Bas. Clin. Pharmacol. Toxicol. 2004, 95,81 .

33. Musilek, K.; Holas, O.; Hambalek, J.; Kuca, K.; Jun, D.; Dohnal, V.; Dolezal, M. Lett. Org. Chem. 2006, 3, 831.

34. Sakurada, K.; Matsubara, K.; Shimizu, K.; Shiono, H.; Seto, Y.; Tsuge, K.; Yoshino, M.; Sakai, I.; Mukoyama, H.; Takatori, T. Neurochem. Res. 2003, 28, 1401.

35. Okuno, S.; Sakurada, K.; Ohta, H.; Ikegaya, H.; Kazui, Y.; Akutsu, T.; Takatori, T.; Iwadate, K. Toxicol. Appl. Pharmacol. 2008, $227,8$.

36. Musilek, K.; Holas, O.; Kuca, K.; Jun, D.; Dohnal, V.; Dolezal, M. Bioorg. Med. Chem. Lett. 2006, 16, 5673.

37. Musilek, K.; Holas, O.; Kuca, K.; Jun, D.; Dohnal, V.; Dolezal, M. J. Enzym. Inhib. Med. Chem. 2007, 22, 425.

38. Musilek, K.; Holas, O.; Jun, D.; Dohnal, V.; Gunn-Moore, F.; Opletalova, V.; Dolezal, M.; Kuca, K. Bioorg. Med. Chem. 2007, 15, 6733. 